\title{
Percutaneous pulmonary valve implantation and related risk of coronary compression - a case report
}

Przeznaczyniowe wszczepienie zastawki płucnej a ryzyko kolizji z tętnicą wieńcową - opis przypadku

\author{
Marcin Demkow ${ }^{1}$, Katarzyna Biernacka², Łukasz Kalińczuk¹, Mateusz Śpiewak¹, Jadwiga Moll³, Piotr Hoffman², \\ Witold Rużyłło
}

${ }^{1}$ Klinika Choroby Wieńcowej i Strukturalnych Chorób Serca, Instytut Kardiologii, Warszawa

${ }^{2}$ Klinika Wad Wrodzonych Serca, Instytut Kardiologii, Warszawa

${ }^{3}$ Klinika Kardiologii, Instytut Centrum Zdrowia Matki Polki, Łódź

4Samodzielna Pracownia Hemodynamiki, Instytut Kardiologii, Warszawa

Post Kardiol Interw 2010; 6, 4 (22): 208-210 DOI:10.5114/pwki.2010.17636

\begin{abstract}
A case of 17-year-old boy with heart catheterisation before planned transcatheter implantation of a pulmonary valve for severe stenosis of his previousely implanted pulmonary homograft is reported. Coronary angiography during simultaneous test inflation of a balloon in the place of homograft stenosis showed severe compression of right coronary artery. This disappeared after balloon deflation. The valve implantation was abandoned. The described test is recommended as a routine before transcatheter pulmonary valve implantation.
\end{abstract}

Key words: pulmonary valve, percutaneous valve implantation

\section{Streszczenie}

Przypadek 17-letniego pacjenta z dysfunkcją (ciasnym zwężeniem), z wszczepionym w okresie niemowlęcym homograftem płucnym, u którego zaplanowano przezżylne wszczepienie zastawki płucnej Melody. W trakcie próbnego wypełnienia balonu w miejscu zwężenia (miejscu, gdzie planowano wszczepienie zastawki) stwierdzono, że doszło do ucisku i powstania ciasnego zwężenia prawej tętnicy wieńcowej biegnącej bezpośrednio z tyłu (za zwężonym miejscem) homograftu płucnego. Po opróżnieniu balonu powrócił prawidłowy przepływ w naczyniu. Chory został skierowany do leczenia operacyjnego. Wykonanie koronarografii w czasie wypełniania balonu w miejscu, w którym planowane jest wszczepienie zastawki płucnej, pozwala ocenić, jak zachowają się tętnice wieńcowe w trakcie ewentualnego zabiegu i powinno być postępowaniem rutynowym.

Słowa kluczowe: zastawka płucna, przeznaczyniowe wszczepienie zastawki

\section{Wstęp}

Przeznaczyniowe wszczepienie zastawki płucnej (ang. percutaneous pulmonary valve implantation) jest obecnie uznaną metodą leczenia chorych z dysfunkcją drogi odpływu prawej komory po operacjach wad wrodzonych serca. Zastosowanie tej metody, korzystniejszej dla pacjenta od kolejnego zabiegu chirurgicznego z powodu mniejszej inwazyjności, mniejszego ryzyka powikłań i znacznie krótszego pobytu w szpitalu, ma jednak istotne ograniczenia.

\section{Opis przypadku}

Pacjent 17-letni, po operacji wspólnego pnia tętniczego z wszczepieniem homograftu płucnego w okresie niemowlęcym, został skierowany do Kliniki z powodu ciasnego zwężenia homograftu. W wywiadach stwierdzano znaczne pogorszenie tolerancji wysitku trwające od 3 lat.

W badaniu echokardiograficznym dwuwymiarowym (2D) metodą Dopplera stwierdzono gradient w drodze odpływu prawej komory wynoszący $100 \mathrm{~mm} \mathrm{Hg}$ oraz

Adres do korespondencji/Corresponding author:

prof. dr hab. n. med. Marcin Demkow, Klinika Choroby Wieńcowej i Strukturalnych Chorób Serca, Instytut Kardiologii, ul. Alpejska 42, 04-628 Warszawa, tel.: +48 2232323 42, faks: +48 2234345 16, e-mail: mdemkow@ikard.pl

Praca wpłynęła 8.06.2010, przyjęta do druku 15.06.2010. 
znacznego stopnia poszerzenie i przerost mięśnia prawej komory.

W celu oceny możliwości wykonania zabiegu przezskórnego wszczepienia zastawki płucnej wykonano rezonans magnetyczny. Uwidoczniono homograft przebiega-

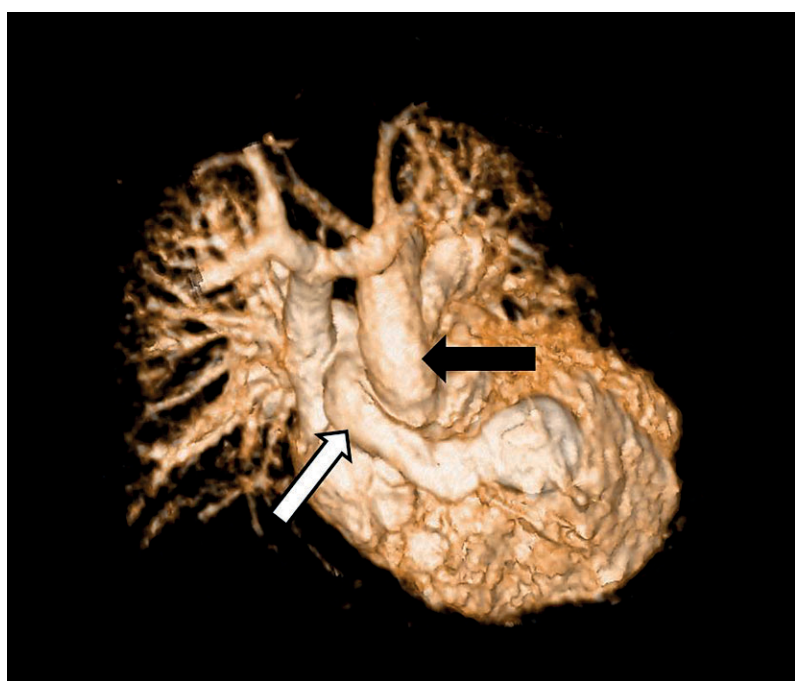

Ryc. 1. Obraz z badania metodą rezonansu magnetycznego serca. Rekonstrukcja 3D badania angiograficznego: homograft (biała strzałka) przebiega z przodu i w poprzek aorty (czarna strzałka), z jej lewej strony na prawą

Fig. 1. A three-dimensional reconstruction of magnetic resonance angiography. The pulmonary homograft (white arrow) is anterior to the aorta (black arrow) going across from the left to the right site

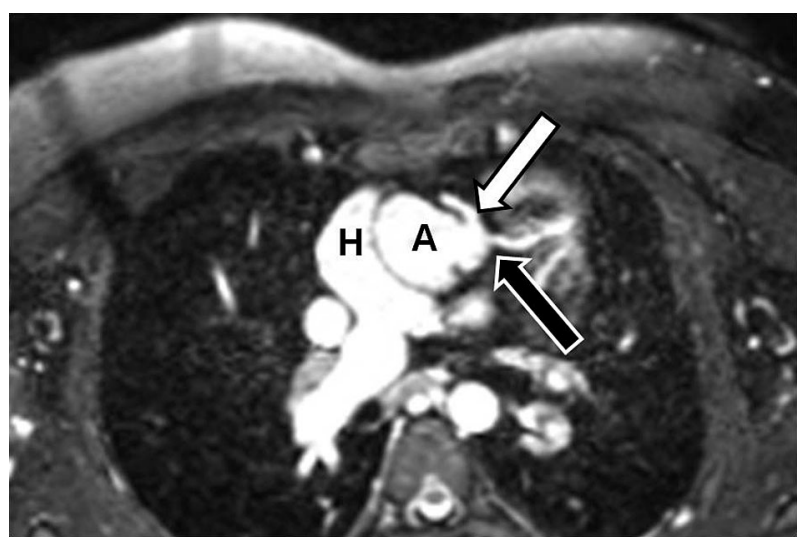

Ryc. 2. Obraz z badania metodą rezonansu magnetycznego serca. Przekrój poprzeczny: widoczne odejście prawej tętnicy wieńcowej (biała strzałka) i gałęzi przedniej zstępującej (czarna strzałka) A-aorta, $H$-homograft

Fig. 2. A two-dimensional magnetic resonance frontal cross-section taken through the aortic takeoffs of the right coronary (white arrow) and the left anterior descending artery (black arrow)

A-aorta, H-homograft jący do przodu i na prawo od aorty wstępującej i dalej między aortą wstępującą a żyłą główną górną (ryc. 1.). Gałąż przednia zstępująca lewej tętnicy wieńcowej odchodziła z prawej zatoki wieńcowej w okolicy odejścia prawej tętnicy wieńcowej (ryc. 2.). Prawa tętnica wieńcowa biegła w bezpośrednim sąsiedztwie homograftu, z tyłu, gałąź okalająca lewej tętnicy wieńcowej odchodziła oddzielnie, najprawdopodobniej z zatoki niewieńcowej (ryc. 3.). Morfologia drogi odpływu i jej wymiary pozwalały na kwalifikację chorego do zabiegu.

W cewnikowaniu serca, przed planowanym ewentualnym wszczepieniem zastawki, stwierdzono ciasne zwężenie $w$ drodze odpływu prawej komory z ciśnieniem skurczowym w prawej komorze $180 \mathrm{~mm} \mathrm{Hg}$ (gradient w drodze odpływu prawej komory wynosił $160 \mathrm{~mm} \mathrm{Hg}$ ). W drogę odpływu prawej komory, w miejsce zwężenia wprowadzono cewnik balonowy (PTS-X 30 mm/4 cm, NuMED). W trakcie jego wypetniania wykonano $w$ dwóch ortogonalnych projekcjach selektywną koronarografię lewej tętnicy wieńcowej oraz aortografię (nie udało się selektywnie zakaniulować ujścia prawej tętnicy). Gałąź przednia zstępująca i okalająca znajdowały się w dużej odległości od homograftu płucnego. Stwierdzono jednocześnie, że doszło do ucisku i powstania ciasnego zwężenia prawej tętnicy wieńcowej biegnącej bezpośrednio z tyłu za zwężonym miejscem homograftu płucnego (ryc. 4.). Po opróżnieniu balonu powrócił prawidłowy przepływ w naczyniu. Chory został skierowany do leczenia operacyjnego.

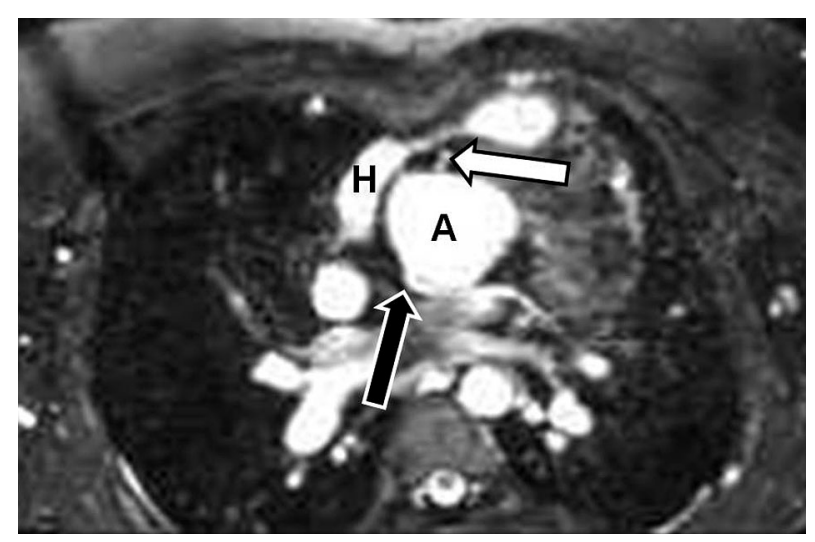

Ryc. 3. Obraz z badania metodą rezonansu magnetycznego serca. Przekrój poprzeczny: widoczny podział prawej tętnicy wieńcowej (biała strzałka) oraz jej przebieg między aortą (A) a homograftem (H). Czarną strzałką zaznaczono miejsce odejścia gałęzi okalającej

Fig. 3. A two-dimensional magnetic resonance frontal cross-section. The right coronary artery bifurcation is seen (white arrow) along with documented vessel course between the aorta (A) and the pulmonary homograft $(H)$. Aortic take-off of the left circumflex artery is indicated (black arrow) 

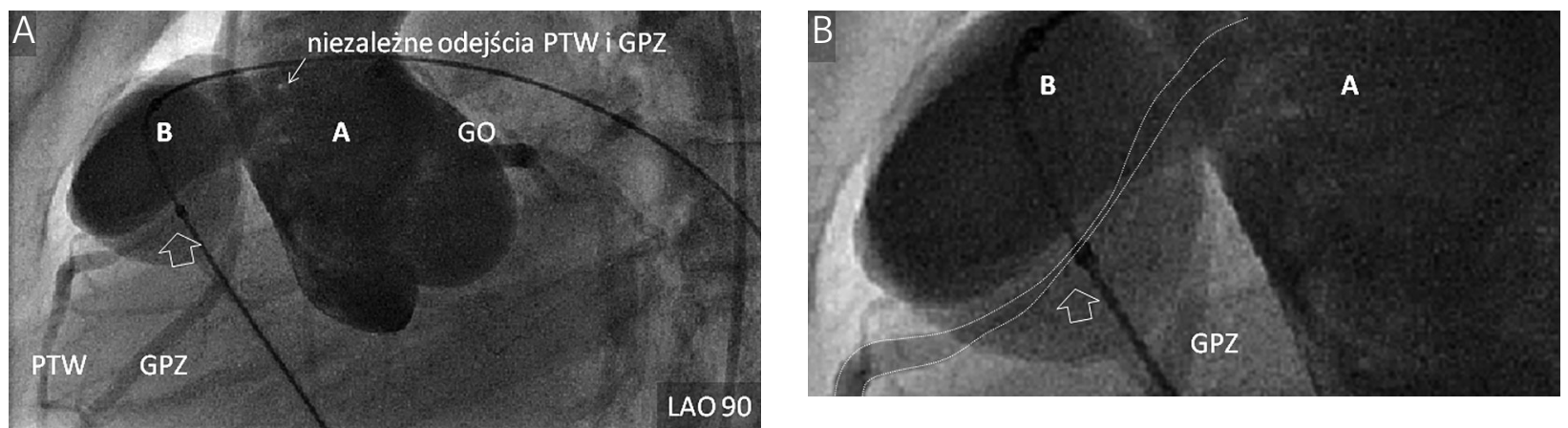

Ryc. 4. Obraz z angiografii (ryc. B to powiększony fragment ryc. A). Serce widziane z boku od lewej strony (LAO 90). Balon (B) wypełniony w homografcie przebiegającym poprzecznie i do przodu od aorty (A). Bezpośrednio do tyłu od homograftu przebiega prawa tętnica wieńcowa (strzałka), która jest uciśnięta przez balon. Na ryc. B obrysowano kontury prawej tętnicy wieńcowej (PTW)

$G P Z$ - gataź przednia zastępująca, $G O$ - gatąź okalająca

Fig. 4. Aortic root angiography taken in 90-degree left anterior oblique while simultaneous inflation of a balloon (B) placed in the pulmonary homograft, which goes across and anterior to the aorta (A). Course of the right coronary artery (PTW) is directly posterior to the homograft and this results in vessel compression documented while/during balloon inflation (arrow). On panel B, which is a magnified part of panel A, drawn is RCA outline $G P Z$ - the left anterior descending artery, GO - the left circumflex artery

\section{Omówienie}

Uciśnięcie tętnicy wieńcowej po rozprężeniu stentu lub zastawki w drodze odpływu prawej komory zostało opisane w pojedynczych doniesieniach i może zakończyć się tragicznie [1-3]. Dlatego niezbędna jest precyzyjna ocena przebiegu tętnic wieńcowych względem homograftu płucnego przed planowanym zabiegiem wszczepienia zastawki płucnej. Wstępną ocenę umożliwia badanie metodą rezonansu magnetycznego. W trakcie cewnikowania serca, przed planowanym zabiegiem, należy jednak dodatkowo wykonać selektywną lub subselektywną koronarografię w czasie wypełniania balonu w miejscu, w którym planowane jest wszczepienie zastawki lub stentu. Manewr ten pozwala nie tylko dokładnie ocenić przebieg tętnic wieńcowych, ale jednocześnie ustalić, jak zachowają się one podczas ewentualnego zabiegu. Procedura ta jest wynikiem zdobytych wcześniej doświadczeń i powinna być postępowaniem rutynowym przed każdym przeznaczyniowym wszczepieniem zastawki płucnej.

\section{Piśmiennictwo}

1. Kostolny M, Tsnag V, Nordmeyer J i wsp. Rescue surgery following percutaneous pulmonary valve implantation. Eur J Cardiothorac Surg 2008; 33: 607-612.

2. Hamzeh RK, El-Said HG, Moore JW. Left main coronary artery compression from right pulmonary artery stenting. Catheter Cardiovasc Interv 2009; 73: 197-202.

3. Sridharan S, Coats L, Khambadkone S i wsp. Transcatheter right ventricular outflow tract intervention: the risk to the coronary circulation. Circulation 2006; 113: e934-e935. 